Division of Geological \& Geophysical Surveys

RAW-DATA FILE 2013-1

\title{
MERCURY INJECTION CAPILLARY PRESSURE RESULTS FROM OUTCROP SAMPLES IN THE INDECISION CREEK MEMBER OF THE NAKNEK FORMATION AND THE KAGUYAK FORMATION TYPE SECTION
}

by

Andrea M. Loveland and PetroTech Associates

$\$ 2.00$

May 2013

THIS REPORT HAS NOT BEEN REVIEWED FOR

TECHNICAL CONTENT OR FOR CONFORMITY TO THE

EDITORIAL STANDARDS OF DGGS

Released by

STATE OF ALASKA

DEPARTMENT OF NATURAL RESOURCES

Division of Geological \& Geophysical Surveys 3354 College Road

Fairbanks, Alaska 99709-3707

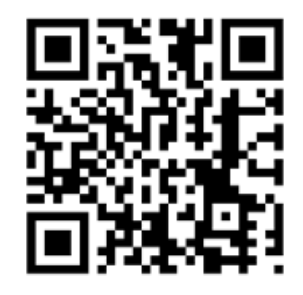





\title{
MERCURY INJECTION CAPILLARY PRESSURE RESULTS FROM OUTCROP SAMPLES IN THE INDECISION CREEK MEMBER OF THE NAKNEK FORMATION AND THE KAGUYAK FORMATION TYPE SECTION
}

\author{
by
}

Andrea M. Loveland ${ }^{1}$ and PetroTech Associates ${ }^{2}$

1 Division of Geological \& Geophysical Surveys, 3354 College Road, Fairbanks, Alaska 99709-3707; andrea.loveland@alaska.gov
2 PetroTech Associates, 11767 Katy Freeway, Suite 320, Houston, Texas 77079

\section{INTRODUCTION}

This report summarizes mercury injection capillary pressure (MICP) data for 19 samples collected from the Indecision Creek Member of the Naknek Formation and the Kaguyak Formation type section. All samples were collected from measured stratigraphic sections, with the exception of sample 12MAW121-b (fig. 1). Measured section sample coordinates represent the location of the bottom of the stratigraphic measured section. All samples were analyzed by PetroTech Associates, Houston, TX.

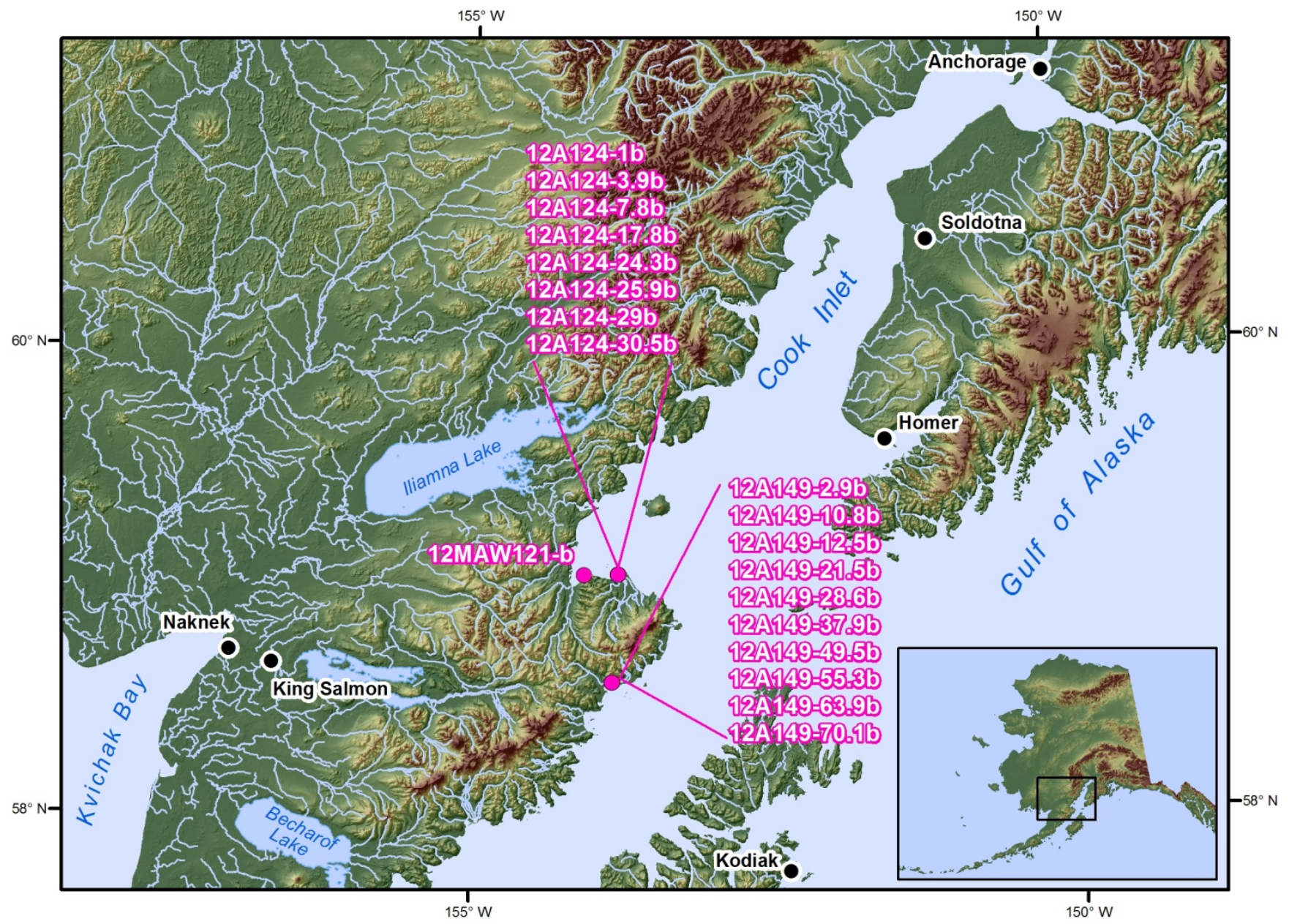

Figure 1. Map showing the Cook Inlet area and the locations from which 19 outcrop samples were collected for MICP analysis. 


\section{DATA FILES}

The data for this publication is provided in its native spreadsheet format. The citation index page for this publication is http://dggs.alaska.gov/pubs/id/24916. The digital dataset includes:

- Sample names, coordinates, the formation from which samples were collected, and brief comments about the samples in this report

- Per/sample pore aperture size distribution charts

- Formation type section pore volume graphs and data

- Pore system properties of the Naknek Formation-Indecision Creek Member and of the Kaguyak Formation

A detailed description of the digital data files can be found in the associated metadata file.

The following pages include correspondence from PetroTech Associates describing the methods used in MICP analyses of the samples in this report, a brief summary of the data, and references cited. 


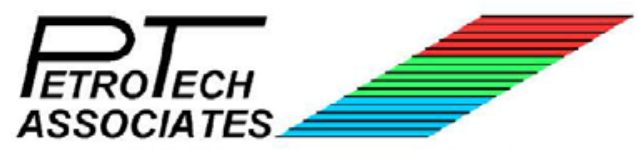

11767 Katy Freeway, Suite 320

Houston, Texas 77079

Tel: 281.558.3996 Fax: 281.558.3998

November 30, 2012

\section{Mr. Trystan Herriott}

Alaska Division of Geological \& Geophysical Surveys

3354 College Road

Fairbanks, AK 99709

Dear Trystan,

PetroTech has completed high-pressure mercury injection capillary pressure analysis of nineteen (19) outcrop samples from the Naknek (9 samples) and Kaguyak (10 samples) Formations (Table 1).

Following receipt of the samples, a representative portion of each was trimmed to fit the sample holders and examined under reflected light microscopy to note any irregularities that might affect the data quality. The rock surfaces were cleaned of any mud or dust and the samples then dried to a constant weight in a low temperature oven before being analyzed.

During capillary pressure testing, the volume of mercury injected was measured at 118 pressure points from 1.64 to 59,500 psia. These data were then corrected for closure. The "closure" volume is the amount of mercury intrusion that occurs as the mercury conforms to the sample surface, filling any irregularities, prior to entering the pore system. A table of the data and separate plots of cumulative bulk volume and wetting phase saturation versus capillary pressure, as well as the incremental pore aperture size distribution, are included for each sample. Composite plots of the drainage data (Figure 1) and pore aperture size distributions (Figure 2), as well as a series of "thumbnail" pore aperture size distribution plots (Figure 3 ) are provided, as an aid when comparing samples.

Table 2 contains the porosity and permeability values derived from the capillary pressure testing. The porosity is based on an Archimedes bulk volume and the closure corrected volume of mercury injected during testing (pore volume). The permeability is calculated using the Swanson equation (SPE, 1981) and the values of cumulative bulk volume and capillary pressure at maximum intrusion. The Kaguyak rocks are generally less porous and permeable compared to the Naknek, although there is some overlap in values (see below).

\begin{tabular}{|l|c|c|c|c|}
\hline & \multicolumn{2}{|c|}{ Porosity } & \multicolumn{2}{c|}{ Permeability (air) } \\
\hline \multicolumn{1}{|c|}{ Formation } & Average & Range & Geomean & Range \\
\hline Naknek & $5.76 \%$ & $3.22-8.13 \%$ & $0.095 \mathrm{md}$ & $0.0088-0.922 \mathrm{md}$ \\
\hline Kaguyak & $3.42 \%$ & $1.96-4.60 \%$ & $0.0006 \mathrm{md}$ & $<0.001-0.0059 \mathrm{md}$ \\
\hline
\end{tabular}


The capillary pressure data is displayed by formation in Figures 1 and 2, and information on the pore system properties is also contained in Table 2. The Naknek Formation samples have pore structures that exhibit varying bimodal character. Initial intrusion occurs through apertures larger than 2 microns (diameter) and intrusion peaks are at apertures ranging in size from 0.54 to 2.5 microns. The exception is the lower porosity and permeability rock (12A124-24.3b) where initial and peak intrusion occur at $<1$ micron and 0.17 microns, respectively. This rock also has more closely spaced initial and secondary peaks. The location of the secondary peak for most of the samples is in the range of 0.044 to 0.015 microns. The proportion of the pore volume accessed by each of the peaks is similar in some of the rocks and in others a majority of the pore volume is controlled by one of the peaks. However, overall the intrusion profiles are relatively broad, indicating the pore structures are heterogeneous.

The Kaguyak Formation samples generally have more restricted pore structures characterized by very broad to poorly defined intrusion profiles. With the exception of samples 12A149-10.8b and $12 \mathrm{~A} 149-12.5 \mathrm{~b}$ the initial intrusion peaks are small and most of the pore volume is accessed by much smaller apertures, in most cases less than 0.01 microns. This pore aperture size distribution is consistent with the much lower permeability of these rocks. As a separate measure of the difference in the pore structures between the two formations, the average median pore aperture size for the Kaguyak rocks ( 0.0297 microns) is much smaller than the value for the Naknek (0.257 microns).

The air/mercury capillary entry pressures for the Naknek rocks are relatively low considering the limited porosity and permeability in these samples. Excluding 12A124-24.3b, the entry pressures average 49 psia (range 15.5-93.4 psia). Sample 12A124-24.3b is more comparable to the Kaguyak rocks, and the 328 psia entry pressure falls within their higher range between 274 and 514 psia (average 402 psia).

PetroTech has assigned project code PA -1186 to this study. We appreciate the opportunity to provide these services. Please contact us with any comments or questions regarding the data or analytical procedures.

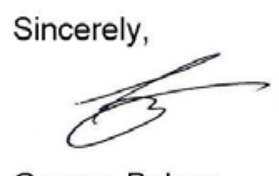

George Bolger

References cited

Sneider, R.M., 1991, Petrophysical properties of seals, in Seals, Traps and the Petroleum System, AAPG Memoir 67; R.C. Surdam (Ed.); American Association of Petroleum Geologists, Tulsa, OK, 317 p.

Swanson, B.F., 1981, A simple correlation between permeabilities and mercury capillary pressures, Journal of Petroleum Technology, pp 2498-2504. 